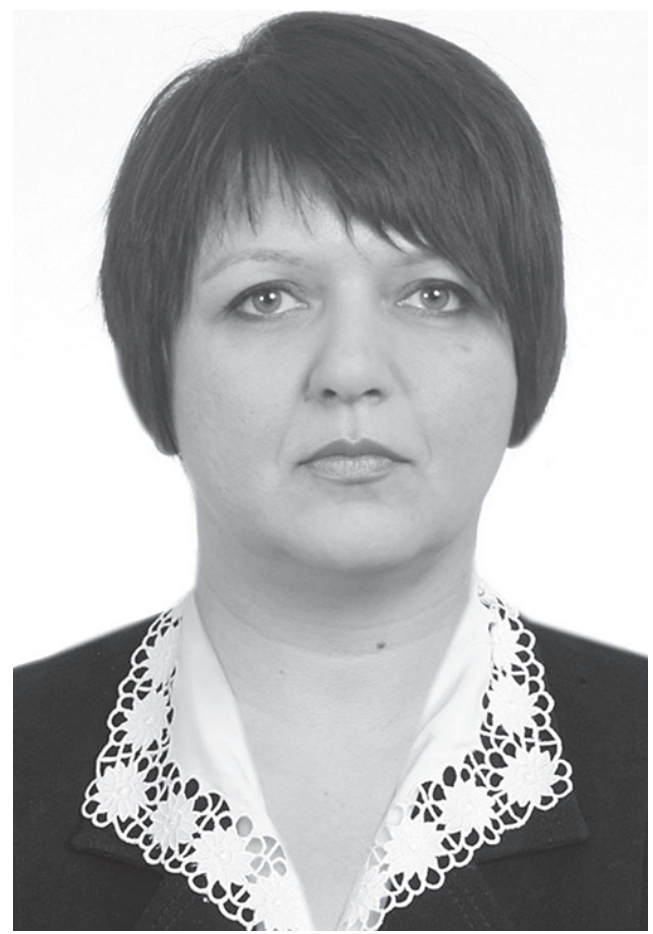

UDC: $\mathbf{3 5 1 . 3 4 2 . 8}$

DOI: https://doi.org/10.32689/2617-

2224-2019-5(20)-24-33

Boyko Olena Petriona,

Candidate of Sciences in Public Administration, Doctoral Student, Department of Public Administration and Public Service, National Academy of Public Administration under the President of Ukraine, 03057, Kyiv, Str. Antona Cedika, 20, nikal@bigmir.net, +38 (067) 447-34-35

ORCID: 0000-0003-3718-1039

Бойко Олена Петрівна, кандидат наук з державного управління, докторант кафедри публічного управління та публічної служби, Національна академія державного управління при Президентові України, 03057, м. Київ, вул. Антона Цедіка, 20, nikal@bigmir.net, $+38(067) 447-34-35$

ORCID: 0000-0003-3718-1039

Бойко Елена Петровна,

кандидат наук по государственному управлению, докторант кафедры публичного управления и публичной службы, Начиональная академия государственного управления при Президенте Украины, 03057, г. Киев, ул. Антона Цедика, 20, nikal@bigmir.net, +38 (067)447-34-35

ORCID: 0000-0003-3718-1039

\title{
THE PROBLEM OF FORMATION OF THE ELECTION COMMISSIONS IN THE SYSTEM OF DEVELOPMENT OF THE FORMS OF REPRESENTATIVE DEMOCRACY IN UKRAINE
}

Abstracts. The article determines that the formation of the election commissions is an important component of the organizational and legal foundations of the electoral process, and therefore it is relevant to identify the main problems of the process. The author states that the procedure for forming the election commissions, in accordance with the national legislation, is determined by the profile election laws, depending on the type of election. The article also analyzes the legal norms that determine the basic dispositions of forming the election commissions. The main problems of formation of the election commissions, such as the principles of recognition of the right to be a member of the election commissions, in par- 
ticular at the local elections, the legal personality of nominating the candidates for positions in the commission, the issues of relations between the subjects and the objects of the submission, the complexity of the professional training of the members of the election commissions. The article analyzes the criteria that limit the citizens' right to the membership in the election commissions. Attention is drawn to the absence of a legal norm for recalling a member of the election commission to the lower level at the initiative of the subject of the submission. The problem is also the unclear regulation of the principles of formation of the main election commission, which is the Central Election Commission. The author also points to the existing system of the education and training of the election commission members. Based on the results of determining the problems of formation of the election commissions at different levels, the author proposes to improve the electoral legislation in terms of improving the professional training of the candidates for the office, strengthening the democracy and at the same time more clearly regulating the procedure for forming the main election commission, which is the Central Election Commission, ensuring the motivation of election commissions and the lower link. The author emphasizes the importance of reviewing the approaches to determining the subject of the election commission membership.

Keywords: elections, election commissions, subject of the formation of the election commissions, Central Election Commission, representative democracy.

\section{ПРОБЛЕМАТИКА ФОРМУВАННЯ ВИБОРЧИХ КОМІСІЙ В СИСТЕМІ РОЗВИТКУ ФОРМ ПРЕДСТАВНИЦЬКОЇ ДЕМОКРАТАТІЇ В УКРАЇНІ}

Анотація. Визначено, що формування виборчих комісій є важливою складовою організаційно-правових засад виборчого процесу, а відтак є актуальним визначення основних проблем процесу. Автор зазначає, що порядок формування виборчих комісій, відповідно до вітчизняного законодавства, визначається профільними законами про вибори в залежності від виду виборів. Проаналізовано також правові норми, що визначають основні диспозиції формування виборчих комісій. Визначено основні проблеми формування виборчих комісій як то принципи визнання права бути членом виборчої комісій зокрема на місцевих виборах, правосуб'єктність висування кандидатів на посади в комісії, питання взаємовідносин суб’єктів та об’єктів подання, складність професійної підготовки членів виборчих комісій. Проаналізовано критерії, які обмежують право громадян на членство у виборчих комісіях. Акцентовано увагу на відсутності правової норми відкликання члена виборчої комісії середнього на нижчого рівня за ініціативою суб’єкта подання. Проблемою також є нечітка регламентація принципів формування головної виборчої комісії, якою є Центральна виборча комісія. Автор зазначає на наявній системі навчання та підготовки членів виборчих комісій. За результатами визначення проблем формування виборчих комісій різних рівнів автор пропонує удосконалення виборчого законодавства в частині підвищення професійної підготовки кандидатів на посади, посилення де- 
мократичності і водночас більш чіткої регламентації порядку формування головної виборчої комісії, якою є Центральна виборча комісія, забезпечення вмотивованості до роботи членів виборчих комісій середньої та нижчої ланки. Автор акцентує увагу на важливості перегляду підходів до визначення суб’єкта подання до складу виборчих комісій.

Ключові слова: вибори, виборчі комісії, суб'єкт формування виборчих комісій, Центральна виборча комісія, представницька демократія.

\section{ПРОБЛЕМАТИКА ФОРМИРОВАНИЯ ИЗБИРАТЕЛЬНЫХ КОМИССИЙ В СИСТЕМЕ РАЗВИТИЯ ФОРМ ПРЕДСТАВИТЕЛЬНОЙ ДЕМОКРАТАТИИ В УКРАИНЕ}

Аннотация. Определено, что формирование избирательных комиссий является важной составляющей организационно-правовых основ избирательного процесса, а следовательно является актуальным определение основных проблем процесса. Автор отмечает, что порядок формирования избирательных комиссий, согласно отечественному законодательству, определяется профильными законами о выборах в зависимости от вида выборов. Проанализированы также правовые нормы, определяющие основные диспозиции формирования избирательных комиссий. Определены основные проблемы формирования избирательных комиссий как принципы признания права быть членом избирательной комиссии в частности на местных выбоpax, правосубъектность выдвижения кандидатов на должности в комиссии, вопрос взаимоотношений субъектов и объектов представления, сложность профессиональной подготовки членов избирательных комиссий. Проанализированы критерии, ограничивающие право граждан на членство в избирательных комиссиях. Акцентировано внимание на отсутствии правовой нормы отзыва члена избирательной комиссии среднего и низшего уровня по инициативе субъекта представления. Проблемой также является нечеткая регламентация принципов формирования главной избирательной комиссии, которой является Центральная избирательная комиссия. Автор также акцентирует на существующей системе обучения и подготовки членов избирательных комиссий. По результатам определения проблем формирования избирательных комиссий различных уровней автор предлагает усовершенствование избирательного законодательства в части повышения профессиональной подготовки кандидатов на должности, усиление демократичности и одновременно более четкой регламентации порядка формирования главной избирательной комиссии, которой является Центральная избирательная комиссия, обеспечения мотивации к работе членов избирательных комиссий среднего и низшего звена. Автор акцентирует внимание на важности пересмотра подходов к определению субъекта представления в состав избирательных комиссий.

Ключевые слова: выборы, избирательные комиссии, субъект формирования избирательных комиссий, Центральная избирательная комиссия, представительная демократия. 
Formulation of the problem. The organizational and legal foundations of the electoral process are the basis for ensuring the legitimacy of the election process and the results of the elections or referenda. The main problems for today in Ukraine are the professionalization of the election commission members, their motivation, political impartiality. The system of the formation of the election commissions should be transformed and aimed at debureaucratization, strengthening of the motivation to work, revision of the sanctions for violation of the current legislation, improvement of the legal education of the candidates for positions.

Analysis of the recent research and publications. Issues of organizational and legal foundations of forming the election commissions in Ukraine have been addressed by such national scientists and practitioners as $\mathrm{O}$. Batanov, N. Bohasheva, A. Voytsekhovska, V. Kovtunets, Y. Klyuchkovsky, O. Marchenko, G. Mykhaylyuk, M. Ryabets, and others. However, the issue of a comprehensive approach to improving the quality of the formation of the election commissions remains poorly understood.

Formulation of the goals of the article. To identify the issues of the formation of the election commissions in the system of development of the forms of representative democracy.

Presentation of the main material. The legal definition of the election commissions is in the current Law of Ukraine "On the Election of the President of Ukraine": "Election commissions are special collegial state bodies authorized to organize the prepara- tion and holding of the elections of the President of Ukraine and to ensure full and equal observance of the legislation of Ukraine on the election of the President of Ukraine" [1]. The same definition is contained in the provisions of the current Law of Ukraine "On Elections of People's Deputies of Ukraine": "Election commissions are special collegial bodies authorized to organize the preparation and holding of the elections of the deputies and to ensure the observance and uniform application of the legislation of Ukraine on the elections of the deputies" [2]. However, the Law "On Local Elections" of Ukraine does not contain such a definition. The determination of the Central Election Commission as a permanent collegial state body "acting on the basis of the Constitution of Ukraine, this and other laws of Ukraine and empowered to organize the preparation and holding of the elections of the President of Ukraine, People's Deputies of Ukraine, deputies of the Verkhovna Rada of the Autonomous Republic of Crimea, deputies of the local councils and village, settlement heads, city mayors, all-Ukrainian and local referenda in the manner and within the limits established by this and other laws of Ukraine" is provided in the Law of Ukraine and "On the Central Election Commission" [3]. As there is currently no legislative support for the local and nationwide referenda, referendum commissions, their definition, status and principles of formation remain uncertain. The procedure for forming the election commissions is determined by the profile election laws, depending on the type of election. The basic legal provisions define the following dispositions: 
1. the right to be a member of the election commission and restrictions on the membership in the commissions,

2. subject of formation of the election commission,

3. subject of nomination of the candidates for the election commissions,

4. timing and regulation of consideration of the submissions to the formation of the election commissions and the procedure for their formation,

5 . the list of documents and the content of the submission for inclusion of the candidates in the commissions,

6. determining the quantitative composition of the election commissions,

7. conditions for inclusion of the nominated candidates in the commissions,

8. general procedure for the formation of the commissions and their management, the conditions of formation in the case of shortages of submissions to the commission, etc.,

9 . issue of replacement of a member of the commission and early termination of the powers of a member of the commission or of the whole election commission,

10. issue of conciliation of the controversial issues in the formation of the commissions, etc.,

11. procedure for publishing the decisions on the formation of the election commissions,

12. special procedure of the formation in case of early elections and in case of simultaneous holding of different types of elections, etc.

With regard to the right to be a member of the election commission, according to the current legislation, such a right is derived from the right to vote: in a national election it is a non-binding voter, and in a local one the members of the territorial community residing in the respective territory have such a right. At the same time, when forming not only territorial but also polling station commissions, according to the current Law of Ukraine "On Local Elections", there were complications in the formation of the electoral commissions precisely because the candidate for the office had to reside within the territory of the respective administrative and territorial unit. [4]. Such logic was laid down by the rules of the CEC Resolution of 03.09.2015 "On clarification on some issues of formation of new composition of territorial election commissions and establishment of precinct election commissions organizing the preparation and conduct of elections of deputies of the Verkhovna Rada of the Autonomous Republic of Crimea, urban, district, district in the cities, rural, settlement councils, rural, settlement, city mayors and heads of the villages, settlements" [5] and is the CEC's own interpretation of the principles of the formation of the precinct election commissions. From our point of view such a restriction is not justified and rational in terms of both the operational formation of the election commissions and the logic of the electoral law: why it is within the administrative-territorial unit and not, for example, on the principle of belonging to the relevant territorial community (in the case of the formation of a Precinct Election Commission) or of a territorial community within a district, a region (when forming the Territorial Election Commission of this level). Such an archaic rule does not take into account the peculi- 
arities of the formation of the united territorial communities and the rights of their members.

The principles of limiting the rights to the membership of the election commissions also need to be revised in the light of the public service reform. Yes, the Law of Ukraine "On the Civil Service" does not apply to the members of the Central Election Commission, but the Law of Ukraine "On the Central Election Commission" defines the status of a CEC member as a civil servant. Therefore, there is a conflict of the legal rules of these laws.

The national electoral law stipulates that certain categories of persons may not be members of the election commissions: minors, non-citizens of Ukraine, hypothetically having a conflict of interest in the office: for example, officials and officials of the state authorities, authorities of the Autonomous Republic of Crimea and local selfgovernment bodies, judges, court and law enforcement officials. The restriction has to do with "running" or representing the interests of the candidate or nominee. The citizens held in penitentiary institutions, detention centers, or convicted of a serious or particularly serious crime, a crime against the suffrage or a corruption offense may not be members of the election commissions, unless the conviction is not extinguished or remedied in accordance with the procedure established by the law. An incapacitated or disabled person also cannot serve as a member of the commission. However, there is no legal mechanism for verifying such data to the commissions of the district, territorial and precinct commissions level. The constituency of the election commission of a special election precinct may not include employees of the respective institution (again to avoid conflicts of interest). The legislator establishes restrictions on the possibility of two or more election commissions simultaneously (except for the members of the territorial commissions who may participate in the work of the commission in the national elections, if such elections are not simultaneous). Specific requirements for the management of the commissions: such as mastering the state language or proper education. For example, the requirements for the CEC members are defined by the Article 7 of the Law of Ukraine "On the Central Election Commission" and have additional to the above requirements and restrictions, for example, termination of the membership in the party, absence of a representative mandate, engage in business activities, be entrusted to third parties in the affairs of the Commission, perform part-time work (other than scientific, teaching and creative activities), be part of the board or other executive bodies of the profit-making organizations. A CEC member may be a citizen of Ukraine who has reached the age of twenty-five on the date of his/her appointment, has the right to vote, has lived in Ukraine for at least the last five years and speaks the state language. The CEC Chairman, the Vice-Chairmen of the Commission, the Secretary of the Commission, as well as at least five other members of the Commission must have a law degree [3].

The issue of the subject of the submission and the principles of consideration of the nominations submitted to the election commissions remains urgent and was particularly acute when 
the Central Election Commission was formed in 2018 and 2019. Pursuant to the Article 6 of the Law of Ukraine "On the Central Election Commission", the Verkhovna Rada of Ukraine appoints and dismisses the members of the Commission on the proposal of the President of Ukraine, which takes into account the proposals of the parliamentary factions and groups formed in the current convocation of the Verkhovna Rada of Ukraine. At the same time the Law stipulates that "the nominations of the persons for the positions of members of the Commission shall be discussed in advance in the parliamentary factions and groups, and their appointment shall be carried out in the presence of the conclusions of the relevant profile committee of the Verkhovna Rada of Ukraine" [3]. In this case the procedure for forming the proposals, whether the "quota principle" for submitting the nominations or the procedure for taking into account proposals, has not been defined. Also, the procedure for rejection of the candidates and the possibility of sabotage by the profile committee in providing these conclusions are not specified.

Equally debatable is the issue of the right to apply for the membership of the lower-level election commissions. The legislator determines the priority in the right of formation of the election commissions in the elections of the local and national deputies of Ukraine by the "parliamentary" parties: their nominees are included in the commissions in a certain number automatically, submission from the "nonparliamentary" parties - by lot. In our view the positive of this principle is the political responsibility and the guar- anteed provision of the organizational component of the elections. However, this reduces the control of the "nonparliamentary" parties by the quality and integrity of the electoral process. This issue is especially relevant for the territorial election commissions that operate on a permanent basis until the next regular elections. It is quite predictable that during the period of the territorial election commissions activity there will be a change of the political elites, and the "parliamentary" party that was the subject of the submission will not have a faction in the Verkhovna Rada of Ukraine of the next convocation. In this case, the legislator does not explicitly provide for neither the rights and obligations of such a party before the object of the submission, nor the legal relationship between them, for example, in matters of replacement or removal of the members of the territorial election commissions. By the way, the domestic legislator did not foresee the issue of withdrawal of the current members of the election commissions at the initiative of the subject of the submission of the middle and lower level (except for the procedure of replacement of a member of the election commission). However, such a rule is possible to apply to a member of the Central Election Commission in accordance with the Article 30 of the Law of Ukraine "On the Central Election Commission". However, such a rule is a possibility of a subjective attitude to the question of the expediency of termination of the powers of a member of the election commission and is a threat to the institutional capacity of the body that administers the election process. 
The most urgent issue is the professional training of the members of the election commissions. Particularly important is the professionalization of the territorial election commissions in the local elections, given that they are permanent bodies. Therefore, the issue of training the participants in the electoral processes is a large-scale task of the state level. Today, the Decree of the President of Ukraine of December 08, 2000 "On the Concept of Enhancing the Legal Culture of the Participants in the Electoral Process and Referenda in Ukraine" is in force, the purpose of which is "enhancing the legal culture of the participants in the electoral process and referenda in Ukraine, ensuring the implementation of the constitutional right of the citizens to participate in the administration of the public affairs, in all-Ukrainian and local referenda, to freely elect and be elected to the state authorities and local self-government bodies" [6]. The Decree of the Cabinet of Ministers of Ukraine "On Approval of Measures to Implement the Concept for Improving the Legal Culture of the Participants in the Electoral Process and Referenda in Ukraine" dated January 31, 2001 No. 88 [7] and the Decree of the Central Election Commission "On the Typical Training Program for the Election Commission Members, Referendum Commissions and Persons Involved in Election Commissions" dated November 21, 2008 No. 65 [8]. In our opinion these documents, which are archaic in view of the changes in the electoral legislation, need to improve the methodology and the search for new tools in the training of the election participants. It is worth noting that the Central Election Commission operates the Center for Training of the Participants in the Electoral Processes, and today a system of distance learning in the online mode "VYBORKOM" is created, which provides not only theoretical knowledge, but also contains materials, samples and forms of documents necessary for the successful performance of their duties.

Conclusions and prospects for further research. In view of the above, it is urgent to improve the electoral legislation in terms of improving the professional training of the candidates for the office, strengthening the democracy and, at the same time, more clearly regulating the procedure for forming the central election commission, which is the Central Election Commission, providing motivation for the work of the members of the middle and lower level election commissions. It is also important to further explore and revise the approaches to identifying the constituents of the election commissions.

\section{REFERENCES}

1. Zakon Ukrainy "Pro vybory Prezydenta Ukrainy" : vid 05 bereznia 1999 roku [Law of Ukraine "On the election of the President of Ukraine" from March 05, 1999]. (1999). Vidomosti Verkhownoi Rady Ukrainy - Bulletin of Verkhovna Rada of Ukraine, 14. Art. 81. Retrieved from https:// zakon.rada.gov.ua/laws/show/474-14 [in Ukrainian].

2. Zakon Ukrainy "Pro vybory narodnykh deputativ Ukrainy" : vid 17 lystopada 2011 roku [Law of Ukraine "On the election of the People's Deputies of Ukraine" from November 17, 2011]. (2012). Vidomosti Verkhovnoi Rady Ukrainy - Bulletin of Verkhovna Rada of Ukraine, 10-11. Art. 73. 
Retrieved from https://zakon.rada. gov.ua/laws/show/4061-17/stru [in Ukrainian].

3. Zakon Ukrainy "Pro Tsentralnu vyborchu komisiiu" : vid 30 kvitnia 2004 roku [Law of Ukraine "On the Central Election Commission" from April 30, 2004]. (2004). Vidomosti Verkhovnoi Rady Ukrainy - Bulletin of Verkhovna Rada of Ukraine, 36. Art. 448. Retrieved from https://zakon2. rada.gov.ua/laws/show/1932-15/ print1443087113377542 [in Ukrainian].

4. Zakon Ukrainy "Pro mistsevi vybory” : vid 14 lypnia 2015 roku [Law of Ukraine "On local elections" from July 14, 2015]. (2015). Vidomosti Verkhovnoi Rady Ukrainy - Bulletin of Verkhovna Rada of Ukraine, 37-38. Art. 366. Retrieved from https://zakon.rada.gov.ua/laws/show/595-19 [in Ukrainian].

5. Postanova TsVK "Pro Roziasnennia shchodo deiakykh pytan formuvannia novoho skladu terytorialnykh vyborchykh komisii ta utvorennia dilnychnykh vyborchykh komisii, shcho zdiisniuiut orhanizatsiiu pidhotovky i provedennia vyboriv deputativ Verkhovnoi Rady Avtonomnoi Respubliky Krym, oblasnykh, raionnykh, miskykh, raionnykh u mistakh, silskykh, selyshchnykh rad, silskykh, selyshchnykh, miskykh holiv ta starost sil, selyshch" : vid 03 veresnia 2015 roku № 217 [Resolution of the CEC "On clarification on some issues of formation of new composition of territorial election commissions and formation of polling station election commissions, which organize the preparation and holding of elections of deputies of the Verkhovna Rada of the Autonomous Republic of Crimea, regional, local, city, local in cities, rural, settlement councils, rural, settlement, city mayors and heads of villages, settlements" from September 03 2015, № 217]. (n.d.). zakon.rada.gov.ua. Retrieved from https://zakon.rada.gov.ua/laws/ show/v0217359-15 [in Ukrainian].

6. Postanova TsVK "Pro Kontseptsiiu pidvyshchennia pravovoi kultury uchasnykiv vyborchoho protsesu i referendumiv v Ukraini" : vid 8 zhovtnia 1999 r., № 336 [Resolution of CEC "On the Concept of Enhancing the Legal Culture of Participants in the Election Process and Referendums in Ukraine" from October 8 1999, № 336]. (n.d.). zakon.rada.gov.ua. Retrieved from https://zakon.rada. gov.ua/laws/show/1322/2000 [in Ukrainian].

7. Postanova KMU "Pro zatverdzhennia zakhodiv shchodo realizatsii Kontseptsii pidvyshchennia pravovoi kultury uchasnykiv vyborchoho protsesu ta referendumiv v Ukraini" : vid 31 sichnia 2001 r., № 88 [Resolution of Cabinet of Ministers of Ukraine "On Approving Measures to Implement the Concept of Enhancing the Legal Culture of Participants in the Election Process and Referendums in Ukraine" from January 31 2001, № 88]. (n.d.). zakon.rada.gov.ua. Retrieved from https://zakon.rada.gov.ua/laws/ show/88-2001-\%D0\%BF [in Ukrainian].

8. Postanova TsVK "Pro Typovu prohramu navchannia chleniv vyborchykh komisii, komisii referendumu ta osib, yaki zaluchaiutsia do roboty $\mathrm{v}$ komisiiakh" : vid 21 lystopada 2008 roku, № 65 [Resolution of CEC "On the Typical Training Program for Election Commissioners, Referendum Commissions and Persons Involved in Election Commissions" from November 21 2008, № 65]. (n.d.). wrere.cvk. gov.ua. Retrieved from https://www. cvk.gov.ua/pls/acts/showcard545e-2. html?id=44327\&ptext $=[$ in Ukrainian]. 


\section{СПИСОК ВИКОРИСТАНИХ} ДЖЕРЕЛ

1. Про вибори Президента України: Закон України від 5 берез. 1999 р. // Відомості Верховної Ради України (1999, № 14, ст. 81). Ст. 23, 24. URL: https://zakon.rada.gov.ua/laws/ show/474-14

2. Про вибори народних депутатів України: Закон України від 17 лист. 2011 р. // Відомості Верховної Ради України (2012, № 10-11, ст. 73). Ст. 27, 28, 29. URL: https://zakon. rada.gov.ua/laws/show/4061-17/stru

3. Про Центральну виборчу комісію : Закон України від 30 квітня 2004 р. // Відомості Верховної Ради України (ВВР), 2004, № 36, ст. 448). Ст. 6, 7. URL: https:// zakon2.rada.gov.ua/laws/show/193215/print1443087113377542

4. Про місцеві вибори : Закон України від 14 липня 2015 р. // Відомості Верховної Ради (2015, № 37-38, ст. 366). Ст. 22, 23. URL: https:// zakon.rada.gov.ua/laws/show/595-19

5. Про Роз'яснення щодо деяких питань формування нового складу територіальних виборчих комісій та утворення дільничних виборчих комісій, що здійснюють організацію підготовки і проведення виборів депутатів Верховної Ради Автономної Республіки Крим, обласних, районних, міських, районних у містах, сільських, селищних рад, сільських, селищних, міських голів та старост сіл, селищ: Постанова ЦВК від 3 вересня 2015 р. № 217. URL: https://zakon.rada.gov.ua/laws/ show/v0217359-15

6. Про Концепцію підвищення правової культури учасників виборчого процесу і референдумів в Україні : Постанова ЦВК від 8 жовтня 1999 р. № 336. URL: http://www.cvk.gov.ua.

7. Про затвердження заходів щодо реалізації Концепції підвищення правової культури учасників виборчого процесу та референдумів в Україні / Постанова КМУ від 31 січня 2001 р. № 88. URL: http://www.cvk.gov.ua.

8. Про Типову програму навчання членів виборчих комісій, комісій референдуму та осіб, які залучаються до роботи в комісіях : Постанова ЦВК від 21 лист. 2008 р. № 65. URL: http://www.cvk.gov.ua 